\title{
Parliamentary Elections in Zimbabwe, 2000
}

\author{
By \\ David Pottie

\begin{abstract}
Dr David Pottie is the Manager of the Democracy Development Unit at the Electoral Institute of Southern Africa, P O Box 740, Auckland Park, 2095, South Africa;
\end{abstract} \\ Tel: +27 11482 5495; Fax: 482 6163; e-mail dpottie@eisa.org.za
}

The 2000 general election was played out against the backdrop of national liberation demands and a Zimbabwe African National Union-Patriotic Front (Zanu-PF) stoking the fires of nationalism. But the Zanu-PF campaign slogan, 'land is the economy, the economy is the land', was not merely revolutionary nostalgia. Rather, it was explicitly backed up by an army of 'war veterans'. and implicitly at least, by the police and armed forces. Leading the charge was President Robert Mugabe, whose populist rhetoric and criticisms of Rhodesian, British, and American interference in Zimbabwean sovereignty added much heat if little light to Zimbabwe's political and economic situation.

The 2000 election promised change, not only in the form of the rising strength of the first substantial opposition to Zanu-PF in Zimbabwe's 20 years of independence, the Movement for Democratic Change (MDC), but also by raising the possibility of succession from within Zanu-PF. Though the election was marked by neither an MDC victory, nor an immediate shake-up within the ruling party hierarchy, it did promise to unleash a profoundly new phase of politics in Zimbabwe.

The first Zimbabwe election was held in February 1980 under the Proportional Representation (PR) electoral system. Zanu-PF won 57 and the Zimbabwean African People's Union (Zapu-PF) won 20 of the 80 African seats in the National Assembly. The United African National Council (UANC) won three seats. The Rhodesian Front (RF) won all 20 of the seats reserved for white settlers. Robert Mugabe became prime minister on 18 April 1980. In the spirit of reconciliation, Mugabe included Zapu-PF members and two white settlers in his cabinet. The leader of Zapu-PF, Joshua Nkomo, was given the Home Affairs portfolio.

\section{Political Background}

Zanu-PF and Zapu-PF were largely supported by the ethnic constituencies of Shona and Ndebele respectively. The Shona constitute $70 \%$ of the population. Serious military clashes repeatedly broke out in the early 1980s in Matabeleland, and the government was accused of using repressive methods and of violating human rights in controlling dissent. The conflict in Matabeleland was two-fold: firstly between dissidents and the government defense units, and secondly between government agencies and all those who were perceived to be Zapu-PF supporters. The conflict was carried out mainly against unarmed civilians in rural areas which traditionally supported Zapu-PF.

In the June 1985 election, the PR system was replaced with a constituency-based system based on first-past-the-post (FPTP). All subsequent elections were held under the FPTP electoral system. Zanu-PF increased its majority to 64 seats, while Zapu-PF won only 15 seats. The Conservative Alliance of Zimbabwe, formerly the RF, won 15 of the 20 seats reserved for whites.

In September 1987, the 20 seats reserved for whites were abolished. In October, further constitutional changes replaced the parliamentary system of government with an executive 
presidency. Following negotiations towards national reconciliation, Zapu-PF was absorbed into Zanu-PF and Joshua Nkomo became the second vice-president.

In the March 1990 election, Zanu-PF secured 117 of the 120 elected seats. In the April 1995 election, Zanu-PF won 118 of the 120 seats, the remaining two going to Zanu-Ndonga (Zimbabwe African National Union-Ndonga), a small opposition party led by Ndanbaningi Sithole. Of the 120 seats, 55 seats were not contested. Eight opposition parties boycotted the April 1995 election.

Since 1995 Zimbabwe has engaged in a long and conflict-ridden process of constitutional debate. The National Constitutional Assembly (NCA), a coalition of over 200 non-governmental organisations (NGOs) and close to 15000 individuals, was formed in 1997 to stimulate debate about Zimbabwe's constitutional order. The government then appointed a Constitutional Commission to draft a new constitution. The majority of its 400 members came from Zanu-PF, including the party's 150 members of Parliament. The NCA refused invitations to be part of the Constitutional Commission, objecting mainly to the fact that the president had selected the commissioners. The NCA campaigned extensively throughout 1999 and into 2000 against the government's constitutional consultative process and argued for a 'No' vote in the February 2000 referendum. Once the draft was completed and presented to the president in December 1999, more than 25 of the 400 commissioners denounced the document as not being a true reflection of the population's views. Twenty-four commissioners did not attend the official hand-over ceremony. A coalition of women's groups threatened not to endorse the draft constitution in the referendum if sections dealing with equality were not amended.

The referendum was held on 12 - 13 February 2000 and the result was a majority 'No' vote. Of 1312738 votes cast, 697754 (55\%) were against the draft and 578210 in favour. The opposition parties welcomed these results as a vote of no confidence in Zanu-PF and President Mugabe, and eagerly awaited the declaration of an election date.

\section{The Electoral System}

The national legislature consists of 150 members. There are 120 single-member constituencies in the country elected on an FPTP basis. A further 30 legislative seats are appointed. Of these, 12 are appointed directly by the president, a further eight people acquire seats on being appointed provincial governors by the president, and the remaining ten seats are reserved for chiefs. These are elected through the electoral college of the National Council of Chiefs and the provincial councils of chiefs (all chiefs are appointed to their chieftainships by the president). Therefore, presidential appointments form 20\% of Members of Parliament.

The Zimbabwean electoral system thus accords enormous power and discretion to the president. The president's powers include the capacity to change electoral law by proclamation after the announcement of an election. Furthermore, in accordance with section 158(2)(b) of the Electoral Act, the president and the minister of Justice, Legal and Parliamentary Affairs are authorised to pass statutory instruments and regulations respectively in relation to the conduct of the election.

Parliament has a five-year term, although this can be extended during times of war or during declared states of public emergency. A general election must be held within four months of the dissolution of Parliament. 


\section{Contested Electoral Administration}

The Electoral Act of 1990 and the constitution provide the legal context for elections in Zimbabwe. The act deals with the appointment and functions of the Delimitation Commission, the Election Directorate, the Electoral Supervisory Commission and the registrar-general of elections.

The act also sets out the preparation and management of the common voters' roll, the election of Members of Parliament, the qualification and disqualification of voters, the conduct of elections and the expenditures allowed in the interests of candidates and the prevention of corrupt or illegal practices in connection with elections.

The electoral machinery in Zimbabwe is complex, with responsibilities divided among three bodies. The first of these is the Electoral Supervisory Commission (ESC), constituted by a chair and four other members who are appointed by the president. The ESC is essentially responsible for ensuring that elections are conducted in a manner that they judge to be free and fair. The ESC has also been traditionally responsible for the accreditation of domestic monitors and international observers. Their reports assist ESC supervision of voter registration and parliamentary elections. However, since the ESC has no constitutional claim on finance or any administrative or executive functions, its main purposes are to report on the conduct of elections and make recommendations about legislative reform. It is highly dependent on the Ministry of Justice for staffing, expenses and other allowances.

In February 2000, the ESC chairperson, Bishop Hatendi, resigned after complaining about the conduct of the registrar-general. To assist its work, the ESC must be provided with reports on registration and other electoral matters by the registrar-general but Hatendi felt that the ESC was being left out of the electoral process. The registrar-general may attend meetings of the ESC but may not vote at the meetings. In accordance with section 61(6) of the constitution, the ESC in exercising its responsibilities shall not be subject to 'the direction or control of any person or authority'. Following Bishop Hatendi's resignation, the ESC was served by an acting chairperson, Mrs Elaine Raftopoulos, with only two other members. A new chairperson, Mr Sobuza Gula-Ndebele, was appointed less than ten days before the election.

During the run-up to the 2000 election, ESC relations with the registrar-general continued to be fractious and the ESC launched two major, but unsuccessful legal challenges in the High Court against him and the government respectively. First, the ESC complained that it had not been involved in the supervision of the registration of voters for the 2000 election, as the electoral law requires. Second, it challenged the government for making changes to the electoral system by decree on 7 June 2000 without consulting the ESC, as required by the electoral law. The decree's reassignment of responsibilities from the ESC to the Election Directorate affected the accreditation of monitors and observers, the eligibility of monitors, and the postal ballot system. The ESC argued that it was the sole body entrusted with supervising elections and accrediting monitors, observers and polling agents under the constitution.

Prior to each election the country's 120 constituencies are subject to a delimitation process undertaken by a Delimitation Commission. This commission is chaired by the chief justice, or a member of the Supreme Court or High Court appointed by the president. Justice Wilson Sandura, who has headed all previous commissions, headed the delimitation exercise for the 2000 election.

On 24 May 2000, only five days before the nomination day for candidates, the commission submitted its final report to the president. The report was then made public on 3 June 2000, merely three weeks before the election. There had not been any public submissions or hearings on the voters' roll owing to the insufficient time available for effective public 
consultation. One opposition MP, Maragaret Dongo of the Zimbabwe Union of Democrats, complained publicly that her constituency boundaries (Harare South) had been redrawn to introduce rural farming areas to dilute her base of support with Zanu-PF voters. Other opposition parties followed suit, claiming that the voters' roll was gerrymandered to favour Zanu-PF as the delimitation report was not published for inspection and comment from members of the public, before it was handed over to the government, as electoral law requires.

One effect of these regulatory changes was to enhance the powers of the registrar-general's office and to reduce the role played by the ESC. The ESC appeared to have neither office capacity nor political support from within the electoral apparatus of the government of Zimbabwe. The acting chair of the ESC stated that the ESC had few resources and was generally unable to effectively carry out its supervisory role and had been unable to acquire the necessary information from other government bodies with responsibility for aspects of the electoral process. For example, she had not been involved in the voter registration process, had no information on the delimitation process and no office staff or budgetary resources to carry out the constitutional role of the ESC.

By contrast, the registrar-general was very confident of his office's role and responsibility for the overall electoral process. The registrar-general is a public servant under the authority of the Ministry of Home Affairs charged with overall administrative responsibility for the conduct of elections. The registrar-general directs the work of constituency registrars, presiding officers, polling officers, counting officers and other electoral officials. Thus while the registrar-general is required to regard any report or recommendation of the ESC, the office is almost entirely responsible for the actual conduct of the elections. As in the case of the Delimitation Commission, the current registrar-general, Tobaiwa Mudede, has held the office since its creation in 1980 .

The delineation of roles has remained a long-standing issue in Zimbabwe and several opposition parties expressed concern about the dependence of the registrar-general on the ruling party and the lack of co-operation between the registrar-general and the ESC.

The final component of election administration in Zimbabwe is the Election Directorate that consists of a chair, appointed by the president, the registrar-general and between two and ten other members appointed by the minister of Justice, Legal and Parliamentary Affairs. The Election Directorate is responsible for co-ordinating the administration by government departments of various electoral tasks including the delimitation of constituencies, the registration of voters, and the conduct of the polls themselves.

The Election Directorate assumed an increasingly important role in the period preceding the election and on 7 June 2000, the Statutory Instrument 161 A of 2000 empowered it to accredit foreign observers on the recommendation of the Ministry of Foreign Affairs.

\section{Pre-election Violence}

The biggest story in this election concerned pre-election political violence and intimidation. Over thirty persons were killed and many more reportedly harassed, beaten and forced to engage in partisan activities (some 5000 according to human rights organisations). The opposition party MDC expressed concern that with over twenty murders since the February referendum police had not yet made a single arrest. The 'land invasions' in which liberation war veterans occupied commercial farms demanding land ownership have been marked by charges of weak or complicit responses by the police and the destruction of property. Throughout the land invasions, Zanu-PF maintained that its party officials, supporters and 
President Mugabe called for restraint and spoke against the political violence, much of which it blamed on the MDC.

By contrast, media and human rights monitors argued that under such conditions free and fair political activity was impossible. In its final election observation report, the domestic monitoring organisation, the Zimbabwe Election Support Network, concluded that the 'violence created an atmosphere of fear and anxiety which had a serious psychological effect on the electorate' and that it was not possible to declare the election free and fair'.

Opposition parties also claimed the land occupations, violence and intimidation were part of a Zanu-PF strategy designed to steal the election. More than 1200 white-owned commercial farms were occupied prior to the election. The opposition parties perceived the motive to be punishment for white farmers who were alleged by the ruling party to have coerced more than one million farm workers to vote against the draft constitution. President Mugabe made a public statement in March 2000 that seemed to confirm this: 'They (the war veterans) are demonstrating their greatest disappointment that there was this 'No' vote which negated the clause in the Constitution that was going to give government power to acquire land without hindrance.'

In the meantime, the Commercial Farmers Union (CFU) successfully petitioned the High Court on 17 March 2000 to have the war veterans removed from commercial farmers' properties. The police appealed against the order, citing limited resources, lack of staff and equipment and the Home Affairs minister, Dumiso Dabengwa, stated that the land issue was too sensitive to be handled purely as a policing matter. On 13 April 2000, the court ruled that the police force had sufficient resources to evict the occupiers and instructed government to meet any additional needs of the force to restore order on the commercial farms. Relations between the CFU and the war veterans remained tense even as various reports of a peace pact continued, evidence that the farmers were uncertain supporters of the MDC. Despite hedging their bets, it became increasingly clear to the farmers as election day approached that Mugabe had no intention of honouring court orders by instructing police or armed forces to remove the land invaders.

International observers on a mission sponsored by the National Democratic Institute for International Affairs (NDI) concluded that a free and fair election was not possible given the pre-election context. The NDI mission cited the land invasions, absence of rule of law, political violence and intimidation, bias in media coverage, and the lack of a level playing field for political parties, among other factors. Zanu-PF spokesperson Jonathan Moyo, publicly castigated the NDI for pre-judging the election and several newspapers, including the government-friendly newspaper, The Herald, followed suit.

Much of the election campaign was thus marred by political violence and intimidation. The prevailing climate of fear had an extreme effect on the electoral process as a whole. Although the levels of violence abated in the immediate weeks before the election, there were still reports of violence until polling day and opposition parties maintained that there were substantial 'no-go' zones under veterans' control.

\section{Election Preparations}

The voters' roll was received by the head of the Delimitation Commission at the beginning of May 2000 and was released to the public on 26 May 2000 and made available for public inspection at prescribed sites. Approximately 5.1 million voters appeared on the roll out of an estimated voting population of six million. 
The leaders of both the MDC and the Zimbabwe Union of Democrats (ZUD) complained that they had no access to the complete voters' roll and that the period for inspection of the voters' roll for the purposes of candidate nomination, let alone widespread verification by voters, was insufficient. On 9 June 2000, the registrar-general was obliged to instruct constituency registrars to open a supplementary voters' roll to include all those who registered between 16 April and 12 June 2000.

Some voters and opposition political parties were concerned that the voters had not been issued with receipts at the time of registration and therefore lacked proof of registration. The registrar-general stated that this was not a concern since the national identification card was all that was needed to confirm one's status on the voters' roll.

Several members of the international community expressed confidence in the voters' roll whereas several opposition political parties and civil society organisations claimed that there had been insufficient consultation and opportunity for public inspection of the roll. The acting chair of the ESC also expressed concern about not being involved in the registration process and her inability to audit the roll.

Opposition parties objected to 29 May 2000, the original date of nomination day. This date would have allowed only one business day (a Friday) for the inspection of the voters' roll before the nomination courts sat to rule on candidate eligibility to stand for election. In a court application, the MDC argued that there had been insufficient time between the publication of the voters' roll and the delimitation of constituency boundaries and nomination day. The MDC won its court case and the court ruled that the candidate nomination period was to be extended to 3 June 2000, thereby allowing the required three weeks for the campaign period before the election on 24 - 25 June 2000.

The general election saw the highest number of women candidates competing for the legislature in the history of Zimbabwean elections. Fifty-five women candidates from five political parties contested the 120 elective seats in the Zimbabwe Parliament (Zanu-PF - 24, MDC - 10, ZUD - 3). Of the 55 women candidates, however, only 14 were elected to Parliament (11\% of the 120 elected MPs).

Zimbabwe's previous Parliament had a 14\% representation of women. These figures are below the 30\% minimum representation target proposed by the 1997 Southern African Development Community Declaration on Gender and Development, which all member states of the regional grouping signed. The declaration sets 2005 as the deadline to reach this goal.

\section{Party Campaigns}

The Zanu-PF campaign centred on the slogan 'Land is the Economy and the Economy is Land'. The party claims for itself status as the only true revolutionary party in Zimbabwe and commits itself to the pursuit of five goals:

- Economic growth;

- Social justice through redistribution of wealth and equality;

- Democracy;

- Peace, stability and the rule of law; and

- National autonomy in domestic and foreign policy.

To achieve these goals, Zanu-PF plans to reduce government expenditure, rectify the foreign exchange crisis, accelerate public enterprise and financial sector reforms, create a National Housing Bank and re-introduce forms of price controls on basic commodities. 
In its prioritisation of land as the central issue in Zimbabwe, the Zanu-PF manifesto argues that:

Our economy is driven by land to the extent that the white minority that owns the best farming and mining land in our country dominates all sections of the economy simply because the majority of our people are landless. However, the Lancaster House Constitution has tied the hands of our Government to prevent it from undertaking the necessary land reform over the first 10 years of independence.

Zanu-PF plans to acquire five million hectares of land from the 12.2 million hectares currently owned by white commercial farmers.

In addition to the land occupations, Zanu-PF had other substantial advantages over its competitors. For example, the Political Parties Finance Act of 1986 provides for the public funding of political parties in Zimbabwe for registered political parties with at least fifteen elected MPs. Parties meeting this threshold are eligible to receive annual funding from the state. These funds are not restricted to election years and the parties receiving funds do not have to return unspent money. Only Zanu-PF has ever benefited from this fund.

Zanu-PF's main competitor, the MDC, was a new party, launched on 11 September 1999 before a crowd of 20000 supporters in Harare. The MDC is led by Morgan Tswangirai, the former secretary-general of the Zimbabwe Congress of Trade Unions (ZCTU), which remains a key source of support along with other civil society organisations. The MDC's manifesto states that industrialisation is the key to economic growth. The party recognises the inequality in land distribution but emphasises the need for transparency and adherence to the rule of law. The manifesto stresses the need to reduce the budget deficit and stabilise the Zimbabwe dollar by re-opening negotiations with the donor community and multi-lateral agencies and accelerating the privatisation of public enterprises. It advocates free health services and free education at primary levels.

The MDC slogan 'Vote for Change' stressed the importance of replacing Zanu-PF with a party that could effectively manage the economy. The MDC blamed Zanu-PF for the violence and intimidation that preceded the election. It receives the majority of its support from the urban areas.

\section{Election Observers}

Prior to the 2000 election, the ESC was responsible for the accreditation of national observers. However, as noted above, in accordance with the Statutory Instrument $161 \mathrm{~A}$ of 2000, in the Electoral (Amendment) Regulations, section 15B(1), issued on 7 June 2000, national monitors were appointed by the ESC and accredited by the registrar-general.

On 20 June 2000, section 15B(1) was amended by the Electoral (Amendment) Regulations to restrict domestic monitors to not more than one per polling station. The Zimbabwe Election Support Network (a coalition of 33 NGOs) had planned to rotate six monitors at each polling station. On 23 June 2000, however, an administrative circular was issued by the chair of the Election Directorate, which stated that despite the statutory amendment, the ESC and the Election Directorate agreed to permit four monitors at each polling station, provided that only one monitor be permitted inside the polling station at any one time. The circular also stipulated that monitors and polling agents be allowed to travel in the vehicles in which the ballot boxes were transported, if there should be room in the vehicle.

The late changes in the regulations governing the numbers and rights of access for national observers meant that the logistical operations for over 24000 trained national 
observers had to be altered twice in the course of the days immediately preceding the election. Owing to these delays, many national observers failed to observe the polling process on the first day of voting. Party agents were also able to observe the voting process and both the MDC and Zanu-PF had party agents at all polling stations.

The accreditation process for international observers was highly politicised, with Zanu-PF stating that no observers from the United Kingdom would be accredited. President Mugabe clearly stated that no British citizens would be welcome as international observers. He said: 'We will welcome any observer team as long as they do not include a single Briton. These young men (British government) are completely ignorant of us.' The largest international observer mission, from the European Union (EU), confirmed that it had not included any British nationals in its main observation team.

As with domestic observers, late regulatory changes added confusion to the process and were clearly designed to delay the deployment of international observers. International observers were accredited by the Election Directorate on the recommendation of the Ministry of Foreign Affairs, in accordance with Statutory Instrument 161A of 2000, gazetted on 7 June 2000. Section 15B(2) stipulates that international observers be accredited by the Election Directorate, on the recommendation of the Ministry of Foreign Affairs. Each international observer was required to pay an accreditation fee of US\$100. Furthermore, the Statutory Instrument Code of Conduct for election agents, polling agents, monitors and observers forbade them to interview voters at polling stations.

New regulations governing the accreditation process were issued in mid-June 2000. Further regulations were to follow. On 19 June 2000, the Election Directorate ruled that individuals representing NGOs would not be accredited as observers in terms of Statutory Instrument 161A of 2000. There were no written criteria on the definition of an NGO and once an international organisation was defined as such, it was immediately disqualified to conduct an observer mission. Similarly, diplomats or representatives of foreign governments were not accredited as observers, since they were already free to move around the country, but not to enter polling stations. Subsequently, the NDI and the International Republican Institute declared that they had been refused accreditation and withdrew from observing the election.

On 21 June 2000, the newly appointed chair of the ESC, Mr Gula-Ndebele, assured international organisations and NGOs that they would be accredited. Subsequently, these groups received their accreditation, some less than 24 hours before the polls were set to open. Finally, diplomats and other international embassy personnel were accredited on 23 June 2000. In the end, over 400 international observers received accreditation.

\section{Election Day and Results}

For all the violence and intimidation, the regulatory manipulation and the highly charged campaigning between Zanu-PF and MDC, the election days themselves were a largely peaceful affair. Most international observers agreed that the polling stations were generally well managed and well equipped. Thus, and surprisingly, given the general political climate in Zimbabwe prior to the election, the polling and counting days were observed to be peaceful and orderly.

Approximately 2.5 million of nearly 5.3 million registered voters cast their ballots. Voter turnout was 48\%. Voter turnout has steadily declined in Zimbabwe, from 94 \% in 1980, to 84\% in 1985, to 54\% in 1990, and 57\% in 1995. In the 1996 presidential election, Robert Mugabe received $93 \%$ of the vote, with a voter turnout of $32 \%$. 
The registrar-general announced the results on 26 June 2000 in Harare. Table 1 indicates the final election results.

\begin{tabular}{lccr}
\multicolumn{4}{c}{ Table 1: Constituency Results, June 2000} \\
Political Party & Votes & Votes \% & Seats \\
\hline Zanu-PFa & 1207298 & 47.23 & 62 \\
MDC $^{b}$ & 1166653 & 45.60 & 57 \\
UPc $^{c}$ & 18606 & 0.73 & \\
ZANU-Ndongad $^{d}$ & 17823 & 0.69 & 1 \\
Zapue $^{f}$ & 11331 & 0.44 & \\
ZUD $^{f}$ & 6201 & 0.24 & \\
Independents & 57622 & 2.25 & \\
Other parties & 3510 & 0.14 & \\
Total & 2556261 & 97.32 & \\
Source: Zimbabwe Election Support Network & & \\
a Zimbabwe African National Union - Patriotic Front & \\
b Movement for Democratic Change & \\
c United Parties & \\
d Zimbabwe African National Union - Ndonga & \\
e Zimbabwe African People's Union & \\
f Zimbabwe Union of Democrats &
\end{tabular}

\section{Conclusion}

With these results Zimbabwe has its first-ever strong opposition, one that very nearly won the majority of elected seats. Had it done so, the MDC would have found itself in an even more highly charged situation, should Mugabe have decided to appoint his thirty seats in a manner that secured a majority of seats for his party while earning a minority of the popular vote. In any event, this scenario did not prevail. The MDC did charge that it was dissatisfied with the results in many constituencies and vowed to press its case in court challenges.

For the future, many administrative and legal issues remain to be settled. The delineation of roles between the ESC and the registrar-general is unclear and lack of resources for the ESC makes it a very weak electoral institution. The debacle around the accreditation of observers reinforced the very real power of elements in the bureaucracy loyal to Zanu-PF. The absence of public consultation and accountability in all aspects of the electoral process, from the constitutional review to delimitation to voter registration through to candidate nomination, builds little confidence in the willingness of the Zimbabwean government to reform its electoral practices.

The fact that voter turnout continues to decline, even in the face of a viable opposition party is still worrying, and continued land invasions and intimidation in by-elections following the 2000 election do not augur well for the future. After all, the presidential election is scheduled for 2002 and despite MDC efforts to press on with an impeachment process, they are unlikely to force Mugabe out of office. The MDC continues to press its case in court in the face of Mugabe's post-election legal manoeuvres to retain power for Zanu-PF. First, through Clemency Order No 1 of 2000 Mugabe pardoned all those accused of political violence and then issued a modification of the Electoral Act invalidating any electoral petitions against the June 2000 results. The MDC has subsequently brought a case against the government in the High Court in support of its court cases in 36 constituencies in which Zanu-PF won. Mugabe has 
also attacked the judiciary on several fronts, from ignoring their rulings to end the land invasions, to attacking white judges for lack of patriotism, to threats to remove such judges from the bench, to the latest attack on the independence and legitimacy of the High Court. These moves, coupled with Mugabe's success at a special party congress in December indicate that he is determined to press on.

To dwell on the fact that the year 2000 closed without success on any of these fronts in part misses the point — for the first time since independence, Zimbabwe has a formidable opposition.

\section{Acknowledgements}

The author wishes to thank Vicky da Silva, Morris Nyakudya and the Electoral Commissions Forum of SADC Countries. 